\title{
How do we densify and socially integrate our cities? On the efficiency of urban property incentives in the vicinity of mass transit stations
}

\section{Cómo incentivar la construcción de ciudades más densas e integradas socialmente? Análisis de la efectividad de incentivos al desarrollo inmobiliario alrededor de estaciones de transporte masivo}

Margarita Greene (Main Author)

Pontificia Universidad Católica de Chile. Facultad de Arquitectura, Diseño y Estudios Urbanos. Escuela de Arquitectura, CEDEUS. Santiago, Chile.

mgreenez@uc.cl

\section{Rodrigo Mora (Contact Author)}

Universidad Diego Portales, Escuela de Arquitectura, Arte y Diseño. Santiago, Chile.

República 180, Santiago, Chile.

rodrigo.mora@udp.cl

\section{Natan Waintrub}

Pontificia Universidad Católica de Chile. Facultad de Ingeniería. Departamento de Ingeniería de Transporte y Logística, Santiago, Chile.

nwaintrub@uc.cl

\section{Cristhian Figueroa}

Pontificia Universidad Católica de Chile. Facultad de Arquitectura, Diseño y Estudios Urbanos. Escuela de Arquitectura, Santiago, Chile.

cofiguer@gmail.com

\section{Juan de Dios Ortúzar}

Pontificia Universidad Católica de Chile. Facultad de Ingeniería. Departamento de Ingeniería de Transporte y Logística, Santiago, Chile.

jos@ing.puc.cl

Manuscript Code: 662

Date of Acceptance/Reception: 20.05.2016/29.07.2015

\section{Abstract}

Stated choice methods were used to measure the effect of different types of incentives (direct and indirect subsidies, changes in building regulations and others) in the willingness to build denser and socially integrated residential projects by real estate firms in the vicinity of metro and bus rapid transit (BRT) stations. A sample of 52 professionals, from building companies and real estate firms, was asked to evaluate a series of urban scenarios under various incentive schemes; in each case they had to choose whether they would be willing to start a conventional residential project (i.e. for buyers belonging to the same socio- economic group) or a socially integrated one (i.e. mixing buyers from different groups). Results show that an aggregate level, only $16 \%$ of respondents would be interested in starting new residential projects at those locations. However, the availability of incentives could have a significant impact in the willingness to initiate higher density projects around the stations and also, but to a lesser degree, in the willingness to initiate socially mixed residential projects.

Keywords: Densification, social integration, public transport, incentives to real-estate agents, direct subsidies, urban rehabilitation, urban sustainability. metro y corredores de transporte público. Un total de 52 profesionales, de empresas constructoras e inmobiliarias, debieron evaluar una serie de escenarios urbanos considerando la existencia de distintos tipos de incentivos y elegir, sucesivamente, en cuáles estarían dispuestos a iniciar proyectos residenciales convencionales (dirigidos a un mismo grupo socioeconómico), o socialmente integrados (que incorporaran grupos de distinto nivel socioeconómico). Los resultados muestran que, a nivel agregado, sólo 16\% de los encuestados estaría interesado en iniciar proyectos residenciales alrededor de las estaciones analizadas. Sin embargo, la aplicación de incentivos podría aumentar en forma significativa la disposición a iniciar obras de densificación y también, aunque en menor grado, a construir conjuntos residenciales socialmente mixtos. 
With almost $90 \%$ of the total country's population (INE, 2002), Chilean cities face important challenges. One is to reduce urban segregation, which mainly affects its principal metropolitan area, Santiago. Another is to increase urban density, mainly at locations that are well interconnected within the cities. This has been recognized in the recently published National Urban Development Policy (PNDU), which recognizes the need to ... "avoid the development of new situations of urban social segregation by means of housing subsidy programs ...", (MINVU, 2014), as well as ..." stimulating the sustainable use of land in cities and expansion areas by means of reutilization processes and high density control towards the interior of central areas", (MINVU, 2014).

Regarding urban segregation, urban policies have been accused of expelling the poor to the periphery of cities, creating large neighbourhoods with no urban services that ... "stimulate despair and, with it, reproduce the vulnerability conditions of its inhabitants, making the development of society as a whole more difficult" (Sabatini \& Brain, 2008). There is no consensus on whether urban segregation is diminishing or not, but experts coincide on its negative effects not only for the inhabitants of poor neighbourhoods but on society in general (Sabatini, Rasse, Mora \& Brain, 2012; López-Morales, 2013; De Mattos, Fuentes \& Link, 2014). On the other hand, urban planning in Santiago has been oriented towards growth in the periphery that is capable of housing a wide array of socio-economic groups. This is evident in the so called conditioned urban development areas (ZODUC), where it is mandatory that at least $30 \%$ of dwellings must be subsidized and $12 \%$ correspond to social houses.

Another mechanism designed to counteract urban segregation has been the diversification of subsidies. For example, the recent modification of the DS49 law (2015) expands peoples' options by means of new forms of habitation (small condominiums) and seeks to avoid the construction of large blocks of social housing in the outskirts of cities. Further, in 2006 a subsidy called "social integration bonus" was implemented, to benefit house buyers in residential complexes where at least $30 \%$ of dwellings are aimed at more vulnerable groups (FS1 or FS2 subsidies). Additionally, the Housing Ministry (MINVU) launched the pilot program "Extraordinary Program of Reactivation with Social Integration" in 2015, which sought to support the construction of residential projects for people with a valid housing subsidy and from different socio economic backgrounds.

Regarding density, a recent study by the Cámara Chilena de la Construcción (2013) found that in the surroundings of the Santiago underground (Metro) there was land available that could absorb the demands of the city for at least 10 years (including stations currently under construction), without the need to change current regulations.

In this context and with the use of advanced econometric techniques, the purpose of this study is to evaluate different incentives to build to build denser and more socially integrated housing projects (around mass transit stations) which may be of interest to real estate developers.

State of the Art

\section{High density surrounding Metro stations and bus corridors}

Inaugurated in 1975, the Santiago Metro has a network of $108 \mathrm{~km}$ distributed over five lines and 103 stations. In addition, two further lines are under construction, which would add $37 \mathrm{~km}$ more to the network and 16 new stations (Figure 1). After the implementation of Transantiago in 2007, an integrated public transport fare system was established, promoting the role of Metro as the backbone of mass transit in the capital city (Muñoz, Ortúzar \& Gschwender, 2009). In fact, close to 2.2 million people travel daily in the Metro network (Metro, n.d.). 


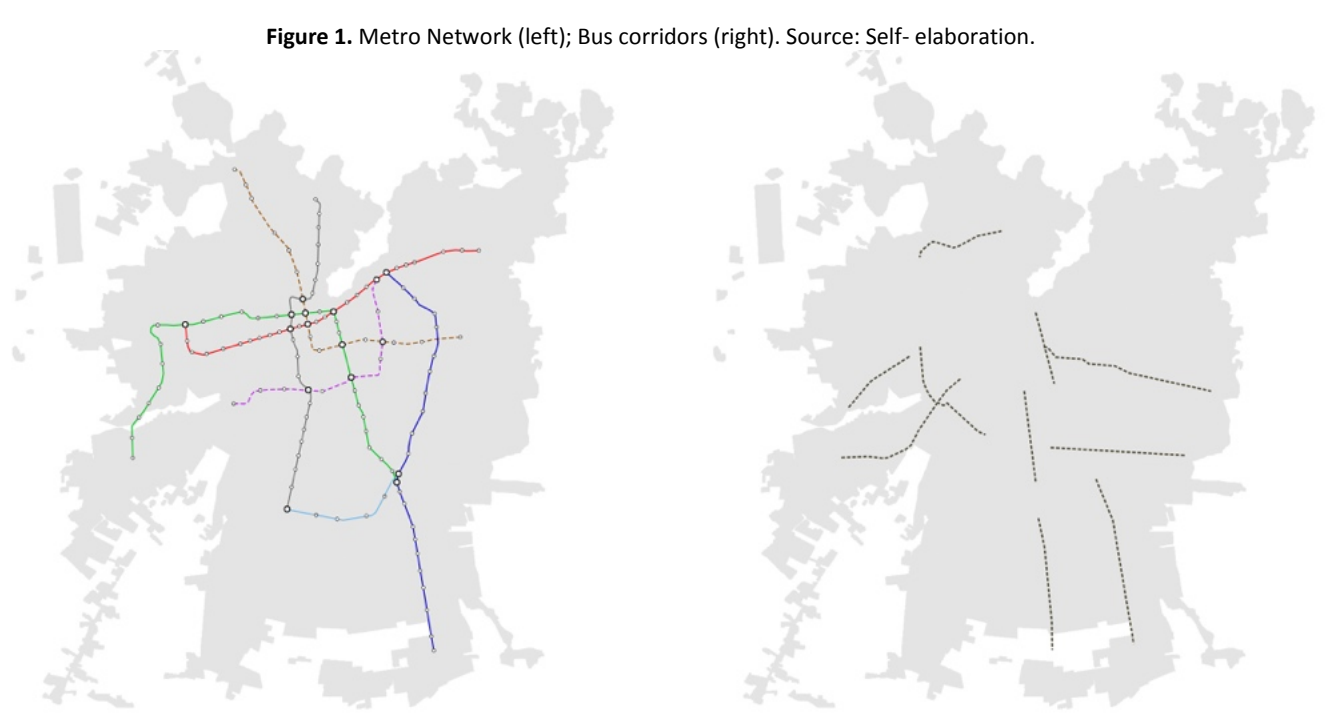

However, in spite of having expanded rapidly in the last two decades and of its importance for urban public transport, the urban effects of Metro seem to be limited. For example, Galilea and Hurtado (1988) claim that Metro "... encouraged speculative dynamics regarding urban structure, more than actually producing a general orientation of this structure". In effect, the impact is unequal; while some areas -such as the northeast sector (Providencia and Las Condes) and the south (San Miquel) - were energized with the arrival of Metro, others such as the western part of the city (Lo Prado and Estación Central) have not shown significant changes in spite of being connected by Metro for more than 40 years.

\section{Subsidies to demand as a social housing policy}

The actual nature of a direct subsidy to demand as a housing policy mechanism has been strongly contested. For example, López-Morales (2013) criticizes this instrument due to its potential contribution to an appropriation by the private sector of urban land rents. This process would not have only been massive, both in monetary and territorial terms, but would have meant that a large part of the original residents (owners and tenants of peri-central areas), were forced to relocate in the periphery. However, authors such as Contreras (2011) or Greene, Mora and Berrios (2011), play down this effect, especially when subsidies have been used as urban renewal mechanism; instead, they value the arrival of new inhabitants to central areas. Further, Rojas (2001) considers that housing subsidies are an efficient and transparent mechanism of public resources allocation which, in addition improves its focus. So, there is no consensus on this issue.

On the other hand, international experience shows that incentives to private real estate developers potentially can produce public benefits. Examples are the well-known Inclusionary Housing initiative (Calavita \& Mallach 2009) or the Chapter 40B (Baker, 2005), both in the USA, where developers are required to allocate a certain proportion of social interest housing in each project in exchange for increments in the allowed density or a reduction in the parking requirements of each project.

This paper sustains that in spite of the different opinions surrounding the allocation of demand subsidies, in practice this mechanism is the main tool used at present by the Chilean government to produce social interest housing and as a strategy for urban renewal. If we assume that at least in the short-term this will continue to be the main mechanism of allocating resources to social housing, the need to study new forms to adapt the instrument, either to generate positive urban effects, such as increases in housing density in zones well-served by mass transit, and/or to reduce residential segregation, is justified.

\section{Discrete Choice Models and Stated Choices}

Stated choice (SC) experiments present a series of choice situations (or scenarios) to a sample of the population under study; these are made up of two or more alternatives described by a finite number of variations of their attribute levels (Rose \& Bliemer, 2009). Respondents are requested to choose the preferred alternative in each situation (Louviere et al. 2000). This information allows to estimate models of discrete choice (Ortúzar \& Willumsen, 2001), assuming an individual utility function which depends on the attributes considered; these models can be used to obtain the probability of choosing an alternative with certain pre-defined attributes. 
Discrete choice models are based on random utility theory (McFadden, 1974); this theory assumes rational individuals endowed with perfect information; that is, each individual always chooses the alternative that maximizes his/her utility. However, the modeller - who is an observer of the system - is not capable of considering all attributes pondered by the individuals, and for this reason requires assuming a random component in utility. Therefore, for the modeller the utility function of each alternative is made up of two parts: (i) a systematic component, known as representative or measurable utility (Viq), which considers only the observed attributes weighted by their relative importance (marginal utility), and (ii) a random component $\left(\varepsilon_{i q}\right)$ so that:

$U_{i q}=\sum_{k} \theta_{k i} x_{i k q}+\varepsilon_{i q}$

where $\theta_{k i}$ are parameters to be estimated; in the simplest version of the approach constant parameter values are assumed for all individuals, but they can vary between options $A_{i} ; x_{i k q}$ is the $k t h$ attribute of alternative $A_{i}$ for individual $q$.

The Multinomial Logit model ( $\mathrm{MNL}$ ), which is simplest discrete choice model, assumes that the errors $\varepsilon_{i q}$ are distributed independent and identically (IID) Gumbel with mean zero and variance $\sigma^{2}$ (Ortúzar \& Willumsen, 2011). In this case, the probability Piq that an individual q chooses alternative Ai is given by the expression:

$P_{i q}=\frac{e^{\lambda V_{i q}}}{\sum_{j \in A(q)} e^{\lambda V_{j q}}}$

where the scale parameter $\lambda$ cannot be estimated separately from the coefficients $\theta_{k i}$ and typically is normalized to one. The marginal utilities $\theta_{k i}$ are estimated by maximizing the likelihood of observing the choices made by the sample.

When SC data is available It is not reasonable to use this simple model as all observations are not independent (i.e. the various choices by each individual are correlated, this is known as panel effect); in this case and in others which violate the basic hypothesis of the MNL (e.g. correlation among alternatives, heteroscedasticity, and taste variations), the preferred model to date is the Mixed Logit (ML), which generalizes the MNL by means of the inclusion of error components in the utility Uiq, which permits considering all of these effects (Ortúzar \& Willumsen, 2011). In the ML, the functional form of the probability is a multiple integral function that requires using simulated maximum likelihood or Bayesian methods to estimate the parameters. In this study ML models were estimated, the details of which are given in Waintrub (2015).

\section{Stated Choice Experiments in Chilean Housing Studies}

There is prior experience in the use of SC techniques to study Chilean housing policies. For example, Greene \& Ortúzar (2010) used SC data and discrete choice models to estimate the relative importance of various social housing attributes by different types of dwellers; they found that, in general, the most valued attributes were the type of dwelling (house vs. apartment) and the building material (brick vs. wood), whereas the size (i.e. number of rooms), distance to the centre of town, and monthly mortgage payment, appeared as less important. More so, with the use of Delphi surveys they found that experts (non-users of the housing units) considered a greater number of attributes as important than the actual users.

Other examples have considered the relative importance of housing and neighbourhood attributes in explaining location at the historical centre of the city (Torres, Greene \& Ortúzar, 2013), as well as the association of urban attributes (and their subjective relative valuation) with citizen fear when walking in poor neighbourhoods (Iglesias, Greene \& Ortúzar, 2013). More recently, SC techniques have been complemented with experiments of the BestWorse type, a type of exercise which results fairly amicable for respondents and allows obtaining good information with regard to the relative valuation of the attributes (Balbontín, Ortúzar \& Swait, 2014). 
The study reported below aimed at establishing the subjective valuation by real estate developers of government incentives to building denser and socially inclusive projects in sectors in close proximity to Metro and BRT stations in Santiago.

\section{Methodology}

We designed a combined SC and best worse experiment focused on 10 Metro stations and four BRT bus stops located at more than 500 meters from a Metro station (Figure 2) and which complied with other desirable requirements (Waintrub, 2015). The selection of the Metro stations was based on a previous study commissioned by MINVU (DICTUC, 2014), which sought to determine areas susceptible to supporting high density and socially inclusive housing in the vicinity of certain Metro stations.

Figure 2. Location of the sample of Metro stations (red) and BRT stops (blue). Source: Self-elaboration.

A face to face survey to 55 real estate professionals was carried out, where respondents were required to have carried out (or being in the process of carrying out), high density housing projects and also projects including demand subsidies for urban renewal. Table 1 shows the characteristics of the chosen sample.

Table 1. Characteristics of respondents. Source: Self elaboration.
\begin{tabular}{|l|r|}
\hline Position & Number \\
\hline General Manager & 16 \\
\hline Area Manager & 15 \\
\hline Area Assistant Manager & 8 \\
\hline Head of Area & 6 \\
\hline Partner, owner or director & 5 \\
\hline Supervisor or area coordinator & 2 \\
\hline Analyst & 2 \\
\hline Consultant & 1 \\
\hline Total & 55 \\
\hline
\end{tabular}

The survey presented respondents with a series of best-worse scenarios, followed by a more traditional SC question, on the basis of a list of previously defined incentives, for up to five locations which were well identified. In the first part, respondents had to indicate the incentive which they found more (best) and less (worse) attractive; then, they had to indicate if with the package of incentives described they would choose to build a high density project in that particular location. If the answer was yes, they were asked if they would be prepared to also incorporate social integration in the project if the incentives were increased. If the answer was no, they were asked if they would be prepared to build the project - including social integration - if the package of incentives was improved.

\section{Identification of Incentives}


The definition of incentives was based upon the current legislation of MINVU, specifically Law N²0.471 of April 2014, which modifies DFL 2 of 1959 of the Ministry of Public Works; it incorporates, in its article eight, the category of "integrated housing projects" designed to help improving the level of urban social integration. In addition, article nine of this law establishes that ... "the Housing and Urban Planning Ministry can set up benefits regarding urban norms for such projects in established places, prior consultation with the respective municipality". Also, and in the same context, it was considered that MINVU could reduce the number of mandatory parking spaces for condos in social housing projects, specifically in those cases associated with public transport.

Based upon the results of the previous study commissioned by MINVU (DICTUC, 2014), a new battery of subsidies that could interest real estate developers to build high density urban housing projects was defined, considering: direct and indirect incentives to supply, as well as direct incentives to demand. Some of these subsidies were currently in operation, such as the direct demand subsidy that has been extensively used in the urban renovation of the central area of Santiago. Both the demand and supply incentives, as well as some indirect subsidies (less common in Chile although considered equally interesting to promote high density housing around Metro stations), are quantifiable measures susceptible of being incorporated into a SC survey.

The study sought to identify first the effect of incentives in the construction of traditional residential units, that is, without any requirement for social diversity among its inhabitants; it also aimed at understanding the extra incentives that would be required to incorporating socio economic diversity in the units (this last scenario was named "with social integration"). A housing unit was considered of mixed type if at least $30 \%$ of the housing units complied with the requirements to receive a subsidy. To define the incentives we used the monetary unit used traditionally in Chile for almost all real estate transactions, the Unidad de Fomento (Unidad de Fomento = UF. The value of the UF at the date of the experiment -July/1/2014, was 24.026 Chilean pesos, and the value of the US\$ then was 553 Chilean pesos. Therefore, one UF was equivalent to US\$ 43,5 at the time of the study), or indexed pesos, which is adjusted daily in accordance with inflation. The characteristics of the incentives (see Table 2) are detailed below.

Table 2. Incentives considered in the SC experiment. Source: Self-elaboration

\begin{tabular}{|l|l|c|}
\multicolumn{1}{|c|}{ Table 2. Incentives considered in the SC experiment. Source: Self-elaboration } \\
\hline \multirow{5}{*}{ Type of Incentive } & \multicolumn{1}{|c|}{ Characteristics } & Amounts \\
\hline \multirow{5}{*}{ Direct to demand } & Bonus to any buyer & 150 UF / apartment \\
\cline { 2 - 3 } & Bonus to buyer with a subsidy & $100 \mathrm{UF} /$ apart. \\
\cline { 2 - 3 } & Bonus for a limited period of time & $150 \mathrm{UF} /$ apart \\
\cline { 2 - 3 } & Increase in the Construction index & $100 \mathrm{UF} /$ apart \\
\cline { 2 - 3 } & Increase in density & $80 \mathrm{UF} /$ apart. \\
\cline { 2 - 3 } & $\begin{array}{l}\text { Reduction of the minimum amount of parking } \\
\text { spaces }\end{array}$ & $30 \%$ \\
\hline \multirow{2}{*}{ Indirect to supply } & Public Investment in public spaces & $50 \%$ \\
\hline
\end{tabular}

\section{Direct Demand Incentives}

- $\quad$ Bonus for any buyer. Amount in UF for apartments in the area in question; however, their value must be equal or less than 2,000 UF.

- $\quad$ Bonus for a buyer who has obtained a subsidy. Amount in UF given to people who already have a housing subsidy or who could qualify for a subsidy (increase in UF above the value of this subsidy); in this case the value of the housing unit associated with this bonus cannot exceed 1,400 UF.

- $\quad$ Bonus for a limited period of time. Amount in UF given to the developer for each apartment built in a housing project if the construction permit is obtained before two years after the date of approval of the decree.

\section{Direct to Supply}

- Increase in the construction index. An increase in the area available for construction, thanks to an increase in the maximum height allowable for construction (this increase can also be achieved by altering other factors affecting the construction index).

- Increase in density. A percentage increase in the number of constructed units in a given area destined for construction, by reducing the factor "inhabitants per housing unit". The figure used to calculate the density of a zone is currently four inhabitants per housing unit, and this has a direct effect in the number of apartments that 
can be built due to the maximum density allowed in the zone. As this factor is currently under study, to change it to three (following data from the last Census), the figure of three was used as base case (representing the current scenario) and variations were presented over this base value in the SC experiment.

- $\quad$ Reduction in the parking requirements. If the current norm required, say, two parking spaces per apartment in the area, and a $50 \%$ bonus was being offered, this meant reducing the requirement to only one parking space per apartment.

\section{Indirect Supply Incentives}

- Public Investment in green areas and/or infrastructure, expressed as an amount (in UF) for each apartment built in the new project. The amount would be invested in ground level green areas or in infrastructure (lighting, trees, urban amenities, among others) to improve the surroundings.

\section{Results}

The models estimated with the combined best-worse and SC data allow estimating the probability that a real estate developer will decide to initiate a residential project in the surroundings of the Metro stations and BRT stops considered (Waintrub, 2015). The results show that without incentives only $16 \%$ of these developers would be willing to initiate residential projects with the purpose of increasing density (conventional projects) in the analysed locations surrounding Metro and BRT stations. This percentage would decrease considerably, to only $6 \%$, if the projects considered social integration. Likewise, the effect of the incentives are unequal if the projects are required or not to incorporate social diversity (see Table 3).

When the project does not require integrating different social groups in a same building, the most effective subsidies are the increase in the construction index (a 30\% increase, predisposes the willingness to construct by $10 \%$ with regard to the base case) and the direct demand subsidies, headed by the bonus to any buyer (an increase of $9 \%$ in the case of UF 150 per apartment), followed by the bonus to buyers with subsidy (an increase of $8 \%$ for both UF 150 and UF 120 per apartment).

On the other hand, the promise of public investment and changes in regulations, such as increases in density, have a relatively lesser effect on the willingness to start up a project (an increase of $5 \%$ and $4 \%$ regarding the situation without incentives); in turn, the reduction of the number of parking spaces has a marginal effect (an increase of only $1 \%$ regarding the situation without incentives). This latter point was relatively predictable as those interviewed expressed that it would be difficult to sell an apartment with insufficient parking spaces.

The efficacy of these subsidies among developers decreases considerably when the real estate project requires social diversity. For example, in the cases of "a bonus to any buyer" and "a bonus to a buyer with a subsidy" of UF 150, the percentage of developers willing to invest in residential projects around Metro stations would go down from $25 \%$ and $24 \%$ respectively, to only $10 \%$ in both cases (see Table 3 ).

Table 3. Probability that a developer invests in scenarios with/without social integration. Source: Self elaboration.

\begin{tabular}{|c|c|c|c|c|c|c|}
\hline Type of incentive & Characteristics & Amount & $\begin{array}{l}\text { Without social } \\
\text { integration }\end{array}$ & $\begin{array}{c}\text { Difference to base } \\
\text { case }\end{array}$ & $\begin{array}{l}\text { With social } \\
\text { integration }\end{array}$ & $\begin{array}{l}\text { Difference } \\
\text { to base case }\end{array}$ \\
\hline \multicolumn{2}{|c|}{ Situation without incentive (base) } & & $16 \%$ & & $6 \%$ & \\
\hline \multirow[t]{6}{*}{ Direct to the demand } & \multirow[t]{2}{*}{ Bonus to any buyer } & 150 UF / apartment & $25 \%$ & $9 \%$ & $10 \%$ & $4 \%$ \\
\hline & & 100 UF / apartment & $22 \%$ & $6 \%$ & $9 \%$ & $3 \%$ \\
\hline & \multirow{2}{*}{$\begin{array}{l}\text { Purchase bonus with a } \\
\text { subsidy }\end{array}$} & 150 UF / apartment & $24 \%$ & $8 \%$ & $10 \%$ & $4 \%$ \\
\hline & & 100 UF / apartment & $21 \%$ & $5 \%$ & $8 \%$ & $2 \%$ \\
\hline & \multirow[t]{2}{*}{ Bonus for a limited time } & 120 UF / apartment & $24 \%$ & $8 \%$ & $10 \%$ & $4 \%$ \\
\hline & & 80 UF / apartment & $21 \%$ & $5 \%$ & $9 \%$ & $3 \%$ \\
\hline \multirow[t]{4}{*}{ Direct to supply } & \multirow{2}{*}{$\begin{array}{l}\text { Increase in ability to } \\
\text { construct }\end{array}$} & $30 \%$ & $26 \%$ & $10 \%$ & $11 \%$ & $5 \%$ \\
\hline & & $20 \%$ & $22 \%$ & $6 \%$ & $9 \%$ & $3 \%$ \\
\hline & Increase in density & $50 \%$ & $21 \%$ & $5 \%$ & $8 \%$ & $2 \%$ \\
\hline & $\begin{array}{l}\text { Reduction to parking } \\
\text { requirement }\end{array}$ & $50 \%$ & $17 \%$ & $1 \%$ & $9 \%$ & $3 \%$ \\
\hline Indirect to supply & $\begin{array}{l}\text { Public Investment in } \\
\text { Public Spaces }\end{array}$ & 75 UF / apartment & $20 \%$ & $4 \%$ & $8 \%$ & $2 \%$ \\
\hline \multicolumn{2}{|l|}{ Average } & & $22 \%$ & $6 \%$ & $9 \%$ & $3 \%$ \\
\hline
\end{tabular}


The results shown in this study indicate several interesting aspects as well as some important questions for the future. First of all, it is evident that the construction of Metro stations or BRT corridors on their own are not sufficient conditions to trigger greater housing density. The aggregate numbers shown here indicate that only $16 \%$ of the real estate developers are likely to invest in the surroundings of this type of transport infrastructure when no incentives exist. This situation changes if individual incentives are applied, and for some the interest to invest increases to $26 \%$ (on average 22\%). In this sense, the most effective incentives were improvements in constructability as well as direct subsidies to demand, with few differences between those open to all, to people with a prior subsidy, or for a limitedtime.

The efficacy of direct subsidies to demand can be explained because it is a known and proven mechanism for real estate developers, and it has been in effect for more than 30 years in Chile. In addition, it assures transparency of the process both at the stage of applying for the subsidy (those who receive them must comply with very clear requirements removed from any political consideration), as well as at the assignment stage (subsidies are delivered based upon explicit technical criteria of MINVU).

On the other hand, the indirect subsidy offered in the study, which consists of an investment by the State in public spaces, had a lesser effect (it would only increase the interest to construct by 4\%).This could be, on the one hand, due to a perception of ambiguity in the allocation criteria (how would it be determined, what type of construction would be carried out, where would it be done, and when would it be carried out?) as well as of execution (who would be in charge of carrying out these works?). It was suggested that in order to improve the efficacy of these type of incentives, it would be necessary to make changes a priori to the Incentives Law (70 bis), linking it to a clear plan of municipal investments and allowing the municipalities to have the faculty to request direct contributions (by means of the delivery of physical housing units or well located land), or indirect (via monetary compensation) to the real estate developers as palliative measures for higher density housing projects in central and peri-central sectors (Sabatini, Mora \& Polanco, 2013).

The acceptance of increments in constructability suggests that, in order to generate housing density around Metro and BRT stations, it would not be necessary to transfer public resources to the private sector, but rather to adapt the existing urban legislation for the so-called "harmonious groups", protecting the morphological, contextual and functional aspects of each housing project with regard to the city (Schlack \& Vicuña, 2011; Contrucci, 2011). The main drawback for this change could come at the political level from the opposition to legal changes aimed at promoting greater housing densities, as it happened recently in districts such as Providencia, Ñuñoa, Santiago or San Miguel.

In addition to the above, we confirmed a certain resistance on the part of real estate developers to carry out residential projects when these incorporated an element of social diversity. Sabatini and Brain (2008) maintain that this conduct has been historically defended by those who oppose social integration, using "naturalist" arguments; that is, as if the resistance of diverse social groups to live in close proximity was merely the continuation of established biological behaviour. The second argument presented against social integration is of an economic character, proposing that this policy would be detrimental to the actual inhabitants as the proximity of lesser income people would reduce the value of their properties. In this light, the resistance on the part of the real estate companies to social integration would just reproduce and probably amplify the segregation tendencies which have formed the current city of Santiago (López-Morales, 2013).

However, national literature shows evidence that at least at a level of inquiry, the resistance to people living in socially integrated groups is less than believed by real estate developers. In a study of 1,779 Santiago residents of different socioeconomic levels, Sabatini et al. (2012) found that more than half of them agreed with the phrase "I think it is commendable that people of different social classes live in close proximity" and just over one third of these people agreed with the phrase. "The majority of people believe that it is a good thing that people of different social classes live close to one another". The greatest resistance to social integration was observed in the higher income level groups, where only $11 \%$ agreed with these statements.

Passing from verb to action has never been an easy task and in this case this step is key to transform the Chilean urban reality and build sustainable cities. Our position in this sense is that the most probable path must include several complementary options.

The exercise carried out aimed at attracting higher income groups to sectors traditionally inhabited by lower income groups, using the Metro as an incentive. Given that this has not occurred spontaneously, a possibility of offering 
government incentives was evaluated so that real estate developers would become interested in developing projects of this nature, relying on the fact that once the benefits were demonstrated these projects would have a demonstrative effect.

Another approach that could be carried out in parallel, would be the construction of exemplary architectural projects that showed the viability of constructing socially integrated projects especially in high income sectors (those most resistant to integration). These measures have already been carried out at the municipal level in the last decade, as well as at the beginning of the nineties. However, up to now they have not received support from the central level. Demonstrative actions have the potential to impact the population in a positive manner because, on the one hand, they permit demonstrating that housing density is not necessarily synonymous with high rises or alterations in the profile of neighbourhoods (Contrucci, 2011), but can also be related with harmonious constructions. On the other hand, they can be indicative that there are other methods to mitigate residential segregation beyond reducing the geographical distance between rich and poor homes using distinctive symbolic aspects, such as fences or walls (as described by Corvalán, 2004; Roitman, 2013).

\section{Acknowledgements}

We would like to thank DICTUC S.A. for sharing with us their data bank. We are also grateful to the Development Fund for Scientific and Technological Research (FONDECYT, Project 1141096), the Complex Engineering Systems Institute (ICM: P-05-004-F; CONICYT: FB0816) and the Centre for Sustainable Urban Development, CEDEUS (Project CONICYT/FONDAP 15110020), for having partially financed this project.

Baker, C. (2005). Housing in Crisis - A Call to Reform Massachusetts's Affordable Housing Law. Boston College Environmental Affairs Law Review, 32(1), 165-206.

Balbontin, C., de Dios Ortúzar, J., \& Swait, J. D. (2014). Importance of Dwelling, Neighbourhood Attributes in Residential Location Modelling: Best Worst Scaling vs. Discrete Choice. Procedia - Social and Behavioral Sciences, 160, 92-101. https://doi.org/10.1016/j.sbspro.2014.12.120

Cámara Chilena de la Construcción. (2013). Estudio de densificación: Identificación del potencial de densificación entorno a la red de Metro de Santiago. Observatorio de Ciudades UC, bajo la dirección de Pablo Contrucci (http://www.cchc.cl/wp-content/uploads/2013/05/Estudio-deDensificación-PABLO-CONTRUCCI.pdf).

Calavita, N., \& Mallach, A. (2009). Inclusionary Housing, Incentives, and Land Value Recapture. Lincoln Institute of Land Policy.

Contreras, Y. (2011). La recuperación urbana y residencial del centro de Santiago: Nuevos habitantes, cambios socioespaciales significativos. EURE (Santiago), 37(112), 89-113. https://doi.org/10.4067/S0250-71612011000300005

Contrucci, P. (2011). Vivienda en altura en zonas de renovación urbana: Desafíos para mantener su vigencia. EURE (Santiago), $37(111), 185-189$. https://doi.org/10.4067/S0250-71612011000200010

Corvalán, F. (2004). Barrios cerrados en Santiago de Chile: entre la exclusión y la integración residencial. EURE (Santiago), 30(91). https://doi.org/10.4067/S0250-71612004009100009

De Mattos, C., Fuentes, L., \& Link, F. (2014). Tendencias recientes del crecimiento metropolitano en Santiago de Chile: ¿Hacia una nueva geografía urbana? Revista INVI, 29(81), 193-219. https://doi.org/10.4067/S0718-83582014000200006

DITUC. (2014). Estudio de densificación en torno a la red de Metro de Santiago. Santiago.

Galilea, S. \& Hurtado, J. (1988). Efectos del metro en la estructura urbana de Santiago. Revista EURE, 14(42), 43-62.

Greene, M., Mora, R., \& Berrios, E. (2011). Original and New Inhabitants in Three Traditional Neighbourhoods: A Case of Urban Renewal in Santiago de Chile. Built Environment, 37(2), 183-198. https://doi.org/10.2148/benv.37.2.183

Greene, M. \& Ortúzar, J. de D. (2002). Willingness to Pay for Social Housing Attributes: A Case Study from Chile, International Planning Studies, 7(1), 55-87, DOI: $10.1080 / 13563470220112607$

Hensher, D. A., Swait, J. D., \& Louviere, J. J. (2000). Stated Choice Methods: Analysis and Applications (First). Cambridge, UK: Press Syndicate of the University of Cambridge.

Iglesias, P., Greene, M., \& Ortúzar, J. de D. (2013). On the perception of safety in low income neighbourhoods: using digital images in a stated choice experiment. In Choice Modelling: The State of the Art and the State of Practic (pp. 193-210). Bingley, UK: Edward Elgar Publishing. https://doi.org/10.4337/9781781007273

INE. (2002). Censo 2002: Síntesis de resultados. Santiago, Chile. Retrieved from http://www.ine.cl/cd2002/sintesiscensal.pdf

López-Morales, E. (2013). Gentrificación en Chile: aportes conceptuales y evidencias para una discusión necesaria. Revista de Geografía Norte Grande, (56), 31-52. https://doi.org/10.4067/\$0718-34022013000300003 
McFadden, D. (1974). The measurement of urban travel demand. Journal of Public Economics, 3(4), 303-328. https://doi.org/10.1016/00472727(74)90003-6

Metro de Santiago (n.d.). Retrieved from http://www.metrosantiago.cl/corporativo

MINVU. (2014). Política Nacional de Desarrollo Urbano, Ministerio de Vivienda y Urbanismo. Santiago, Chile. Retrieved from http://cndu.gob.cl/wpcontent/uploads/2014/10/L4-Politica-Nacional-Urbana.pdf

Muñoz, J. C., Ortúzar, J. de D., \& Gschwender, A. (2009). Transantiago: the fall and rise of a radical public transport intervention. In Travel Demand Management and Road User Pricing: Success, Failure and Feasibility (Transport and Mobility) (p. 268). New York, USA: Routledge.

Ortúzar, J. de D. \& Willumsen, L. G. (2011). Modelling Transport (4th ed.). Chichester, UK: John Wiley \& Sons, Ltd.

Roitman, S. (2013). Close but Divided: How Walls, Fences and Barriers Exacerbate Social Differences and Foster Urban Social Group Segregation Housing, Theory and Society, 30(2), 156-176. https://doi.org/10.1080/14036096.2012.728150

Rojas, E. (2001). The Long Road to Housing Sector Reform: Lessons from the Chilean Housing Experience. Housing Studies, $16(4), 461-483$. https://doi.org/10.1080/02673030120066554

Rose, J. M., \& Bliemer, M. C. J. (2009). Constructing Efficient Stated Choice Experimental Designs. Transport Reviews, $29(5)$, 587-617. https://doi.org/10.1080/01441640902827623

Sabatini, F., \& Brain, I. (2008). La segregación, los guetos y la integración social urbana: mitos y claves. Revista EURE, 34(103). https://doi.org/10.4067/S0250-71612008000300001

Sabatini, F., Mora, P., \& Polanco, I. (2013). Control de la segregación socio-espacial: Rebatiendo mitos, construyendo propuestas. Santiago. Retrieved from http://www.espaciopublico.cl/wp-content/uploads/2016/05/17.pdf

Sabatini, F., Rasse, A., Mora, P., \& Brain, I. (2012). ¿Es posible la integración residencial en las ciudades chilenas?: Disposición de los grupos medios y altos a la integración con grupos de extracción popular. Revista EURE, 38(115), 159-194. https://doi.org/10.4067/S0250-71612012000300008

Schlack, E., \& Vicuña, M. (2011). Componentes normativas de alta incidencia en la nueva morfología del Santiago Metropolitano: una revisión crítica de la norma de "Conjunto Armónico." Revista EURE, 37(111), 131-166. https://doi.org/10.4067/S0250-71612011000200006

Torres, I., Greene, M., \& Ortúzar, J. de D. (2013). Valuation of housing and neighbourhood attributes for city centre location: A case study in Santiago. Habitat International, 39, 62-74. https://doi.org/10.1016/j.habitatint.2012.10.007

Waintrub, N. (2015). Disposición a recibir incentivos para desarrollo inmobiliario en densidad en torno a estaciones de metro y corredores de buses. MSc Thesis, Pontificia Universidad Católica de Chile, Santiago, Chile. 